\begin{tabular}{|c|c|c|c|c|c|c|}
\hline \multirow{4}{*}{ Impact Factor: } & ISRA (India) & $=3.117$ & SIS (USA) & $=0.912$ & ICV (Poland) & $=6.630$ \\
\hline & ISI (Dubai, UAI & $=0.829$ & РИНЦ (Russia) & $=0.156$ & PIF (India) & $=1.940$ \\
\hline & GIF (Australia) & $=0.564$ & ESJI (KZ) & $=8.716$ & IBI (India) & $=4.260$ \\
\hline & JIF & $=1.500$ & SJIF (Morocco) & $=5.667$ & OAJI (USA) & $=0.350$ \\
\hline
\end{tabular}

\section{SOI: $1.1 /$ TAS $\quad$ DOI: $10.15863 /$ TAS International Scientific Journal Theoretical \& Applied Science}

\author{
p-ISSN: 2308-4944 (print) e-ISSN: 2409-0085 (online) \\ Year: $2019 \quad$ Issue: $06 \quad$ Volume: 74
}

Published: $19.06 .2019 \quad$ http://T-Science.org
QR - Issue

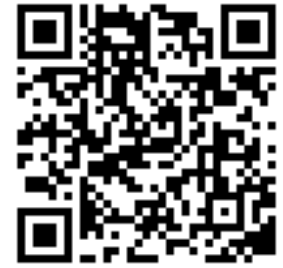

QR - Article

Zoxidaxon Yo'ldashevna Kholmirzayeva

Namangan teachers' training and qualification institute senior teacher of

the department of natural and exact methods

\title{
USING THE SCIENTIFIC INFORMATION ON THE "CHEMISTRY HISTORY" COURSE LESSONS
}

Abstract: This article contains the scientific data on the history of chemistry and industry of Uzbekistan, its present state and prospects in the Fergana valley. Besides, it gives the information on the presence of macro and microelements in Uzbekistan and their effects on the human body, dye and medicinal herbs.

Key words: microelement, dye, extract, copper, manganese, lead, cement.

Language: English

Citation: Kholmirzayeva, Z. Y. (2019). Using the scientific information on the "Chemistry history" course lessons. ISJ Theoretical \& Applied Science, 06 (74), 312-314.

Soi: http://s-o-i.org/1.1/TAS-06-74-38 Doi: crossef https://dx.doi.org/10.15863/TAS.2019.06.74.38

\section{Introduction}

The "Chemistry History" course is included in the curriculum as a subject of study in chemistrytechnology and chemistry faculties of higher educational institutions of the Republic of Uzbekistan and higher educational institutions, which train chemistry teachers. "History of chemistry" should play a connecting role (integrative) in the system of chemistry subjects. This course is designed to establish links between natural sciences and humanitarian subjects. [1-2]

Based on interviews with students, we have come to the conclusion that the course will be of great interest to future specialists.

Knowing the history will equip them with modern knowledge and will help them to understand the modern chemistry consciously. In the recommended textbooks and manuals [1] on this course, the scientific data about the past and present of the chemical science and industry of Uzbekistan are not sufficiently given.

There are roots of chemistry history in the Fergana Valley. Archaeologists have discovered the remains of the Stone Age and other eras. Older manuscripts, scientific and religious sources have a lot of interesting information.

The Fergana Valley is a naturalized region of the world, surrounded by mountains on all sides. The caravans of the Great Silk Road passed this land, and travelers from China, Spain and other countries wrote a lot about it.

\section{Materials and Methods}

In the past, the town of Axsikent was compared to Afrasiyab settlement in Samarkand. Ferghana, Andijan, and Namangan emerged after the destruction of the ancient city of Ahsikent and they were its successors. Many architectural designs of the old settlement, the availability of a bath, the water supply network, and the metropolitan construction methods have shown that the intellectual potential of the people living there is very high. [7]

There are an abundance of data concerning the valley's mining resources. The Chinese gold seekers wrote that the foothills of the Fergana valley were rich in gold, silver metals, iron ores, rare earth elements, and mercury extraction was a special measurement in this time. We have included this information into the subject of "History of Chemistry".

The Fergana Valley's plants require giving the sanctuary status to it because of its heritage, diversity, rarity and protection. Plants are taken food with minerals. Recent scientific publications and references have provided a load of information on the study of chemical composition of medicinal plants and food products.

Despite the fact that today there are many highperformance synthetic drugs, great attention is being paid to the study of medicinal plants, in particular, the study of the macro and microelement content of plants.

The presence or absence of macros and micronutrients affects the human body and vital activity. Therefore, the important task is to determine 


\begin{tabular}{|c|c|c|c|c|c|c|}
\hline \multirow{4}{*}{ Impact Factor: } & ISRA (India) & $=3.117$ & SIS (USA) & $=0.912$ & ICV (Poland) & $=6.630$ \\
\hline & ISI (Dubai, UAI & $=0.829$ & РИНЦ (Russia & $=0.156$ & PIF (India) & $=1.940$ \\
\hline & GIF (Australia) & $=0.564$ & ESJI (KZ) & $=8.716$ & IBI (India) & $=4.260$ \\
\hline & JIF & $=1.500$ & SJIF (Morocce & $=5.667$ & OAJI (USA) & $=0.350$ \\
\hline
\end{tabular}

their microelement content. We studied the paint and medicinal plants of Ferghana and Namangan regions, and also focused on negative impacts according to ecological trends.

The results of the research show that many natural plants can be used in dyeing and dyeing of various fibers. The dyeing can be made entirely by the plant organs, as well as with aqueous or organic extracts. That is why, the researches have been conducted in this direction. When the extract is taken from plant organs, 3 times less than the copper, 60$80 \%$ manganese, $40-60 \%$ lead, $20 \%$ nickel, $22-28 \%$ of iron remain, that is, it is clear that these elements are extracted and dyeing occurs in the presence of these metals and demonstrates the presence of these metals in the extract.

The carpets that are painted with natural dyes are now gaining the attention of art lovers.

The presence of water-soluble metal compounds in extracts increases the medicinal properties of plants, which can be clearly seen in the use of valerian root.

Our scientists have a great contribution in increasing the fame of our country. Regarding this, there are a great number of scientists in creating and developing miraculous science in our country. On the eve of the 11th anniversary of independence of our country, by the decree of the first president of Uzbekistan, a group of late leaders of our state, who made a great contribution to the science, were awarded due to their Great Services. Among them there was the great scientist and skillful person, founder of the bioorganic chemistry school in Uzbekistan, academician ObidSodikov. [8] Scientific, pedagogical, social and organizational activities of $\mathrm{O}$. Sodiqov are admired well by the scientific community of our country. In 1966, the teacher was a member of the Academy of Sciences of Uzbekistan, a correspondent member of the Academy of Sciences of the former Soviet Union, and 1992 as an academician. O. Sodiqov worked at the Academy of Sciences of the Republic of Uzbekistan during this period in order to maintain an intimate relationship between science and production. In 1966-1984 a number of new research institutes were established in the Academy of Sciences, including the Department of Electronics, Biochemistry, Archeology, Thermophysics, Bioorganic Chemistry Institute, Cybernetics Scientific Production Association, Polymer Chemistry and Physics Institute and others. O. Sodiqov paid a great attention to the comprehensive study of cotton and cotton waste. It has proven that it is possible to get food acids and biological stimulants from the cotton plant. As a result, the production of protein-vitamin supplements for livestock began to emerge from cotton plants. Under the guidance of the scientist, more than 50 million sums have been earned. Under the guise of O. Sodiqov, the inexpensive way to get itaconic acid has made a great contribution to the development of the artificial silk manufacturing industry.

Obid Sodiqov, the founder of the world-famous Uzbek science bioorganic chemistry school, is always alive. [5]

Yunusov S. - Academician of the Academy of Sciences, Doctor of Chemistry, Professor, author of more than 600 scientific articles, over 100 inventions, more than 10 monographs. He has mentored more than 10 doctors of sciences, more than 100 Candidates of Science. In 1969, he was awarded the title of Hero of Labor. He was awarded with the gold medallion named after I. Mendeleev.

In 1959, S.Y.Yunusov was awarded the title "Honored Science and Technician of Uzbekistan" for his great services. In 1962, S.Y.Yunusov was elected as an academician of the German naturalists at the Leopold Academy. In Uzbekistan, there are more wild plants than any other country, but not all of them have been fully studied from chemical viewpoint. In 1959, on the basis of the Laboratory of Alcohol Chemistry, the Institute of Plant Chemistry of the Academy of Sciences of the Republic of Uzbekistan was established in order to address these issues in full. [2]

I.R.Asqarov graduated from the API (1949), a teacher of the general chemistry department of ADU (1970-72), a scientific worker at ToshTI (1972-75), and a Ph.D. (1975). He was a researcher at Moscow Institute of Chemistry of Elements of Organic Connections (1980-82), Science Doctor (1990), honored inventor and rationalizer in Uzbekistan, professor of ADU. Asqarov I is an author of more than 400 works, 58 methodical manuals, secondary textbooks for 7,8,9 grades. He has mentored $18 \mathrm{PhDs}$, 2 Doctors of Science, is a head of 10 Food companies. $\mathrm{He}$ has been working on organic chemistry, classification and certification of chemicals.[1]

Y.T.Tashpulatov. Yo'lchiTashpulatov was one of the "The Thirteen Swallows". He was the first doctor of technical sciences among the Uzbek people. Although not long-lived, he made a significant contribution to the development of science and technology.

In 1939, he conducted his $\mathrm{PhD}$ thesis on "The effect of Portlandcement on glinosis on its saltresistant properties." The scientist has worked on obtaining fresh and saline water resistant cement based on burned soil and portland cement. In order to be resistant to sulphurous water, Portland Cement has a very large amount of content (up to 70\%) naturally burned - instead of gilding, Ahangarankaolinit has been developed with Portland cement, which is resistant to sulfuric water, based on soil and ordinary portland cement. The new product is called glinitportlandcement. Glinit-portlandcement is distinguished by its technical advantages, frostresistant and strong. The cement created by the scientist soon began to produce at the Bekabad cement plant on an industrial scale. He was an author of 


\begin{tabular}{|c|c|c|c|c|c|c|}
\hline \multirow{4}{*}{ Impact Factor: } & ISRA (India) & $=3.117$ & SIS (USA) & $=0.912$ & ICV (Poland) & $=6.630$ \\
\hline & ISI (Dubai, UAE & $=0.829$ & РИНЦ (Russia & $=0.156$ & PIF (India) & $=1.940$ \\
\hline & GIF (Australia) & $=0.564$ & ESJI (KZ) & $=8.716$ & IBI (India) & $=4.260$ \\
\hline & JIF & $=1.500$ & SJIF (Morocce & $=5.667$ & OAJI (USA) & $=0.350$ \\
\hline
\end{tabular}

"Glinitportland-cement" monography and more than 50 scientific articles. [3]

We have been using these resources to conduct lectures and seminars.

Thus, the following words of D. Mendeleyev are worthy of note: "Knowing ready conclusions easily without information how to make them may lead to confusion". These words fully explain the essence of an integrative approach to the study of chemistry. [4]

\section{Conclusion}

The abovementioned conclusions show that the issues of the history of chemistry should be based on the use of scientific information, specific chemical phenomena, and aggregation. In addition, the introduction of historical knowledge into the teaching of specific sciences will help to improve the quality of education.

\section{References:}

1. Asqarov, I. (2014). O'zbekiston kimyogar olimlari. Ma'lumotnoma. Toshkent.

2. O'rinovningtahririostida A. Q. (2003). "Farg 'onaDavlatUniversitetiolimlari" bibliografikma'lumotlar. (p.142). Farg'ona.

3. Parpiev, N., Rahimov, X., \& Muftaxov, A. (2000). "Anorganikkimyonazariyasoslari", “O'zbekiston”. (p.478). Toshkent.

4. (2019). O'zbekistonkimyositarixidan. Maktabdakimyojurnali, № 4.2019, Toshkent, p.32.

5. Ismoilov, I., \& Nishonov, M. (2011). "Ustozlarxotirasiabadiydur"

(“Kimyota'limisamaradorliginioshirishomillari "mavzusidagiRespublikailmiy-

amaliyanjumanningmateriallari). (p.281).

Farg'ona.
6. Abdullaev, S., Karimov, Q., \& Qo“qonova, N. (2007). "O'zbekistonkimyogarlari”. (p.48). Namangan.

7. Hoshimova, S. (2009). "Abu Bakr Muhammad ibn ZakariyoAr-Roziy”. Maktabdakimyojurnali № 6, Toshkent, p.32.

8. (2011). "O'zbekistonda kimyosanoatiistiqbollari” "XXI asrtexnologiyalari” ilmiy-texnikaviyjurnal. № 4(5), Toshkent, p.32.

9. Tilyabaev, Z. (2011). "O'zbekfaninidunyogatanitganolim", "XXI asrtexnologiyalari” ilmiy-texnikaviyjurnal, № $4(5)$, p.32.

10. Ahmerov, K. (1987). "O 'zbekistonkimyogarlariningmuvaffaqiyati”, Toshkent: Fan.

11. Qamchibek, K., \& Jasorat, M. (2012). rifiybiografikqissa. Toshkent: Tafakkur'. 